\title{
Student-initiated email communication: An analysis of openings and closings by Spanish EFL learners
}

\author{
Patricia Salazar Campillo - Universitat Jaume I \\ csalazar@uji.es
}

Rebut / Received: 11-7-17

Acceptat / Accepted: 23-1-18

Resum. Comunicació per correu electrònic iniciada per l'estudiant: Una anàlisi de les obertures i els tancaments usats per estudiants espanyols d'anglès com a llengua estrangera. El correu electrònic és una de les formes de comunicació més utilitzades en el context institucional i, de fet, abunden en la interacció professor-estudiant. Aquest estudi analitza les obertures i els tancaments en els correus electrònics de primer contacte enviats per dos grups d'estudiants amb característiques similars: un grup va usar la seva llengua materna (espanyol) i el segon la llengua estrangera (anglès) al realitzar una petició a un dels seus professors. Els resultats indiquen que, independentment de la llengua utilitzada, les obertures no han demostrat el nivell de formalitat esperable en aquest tipus d'enviament. Per contra, en els tancaments es detecta deferència i respecte al professor en els dos idiomes.

Paraules clau: obertures, tancaments, correu electrònic, distància de poder.

\begin{abstract}
Student-initiated email communication: an analysis of openings and closings by Spanish EFL learners. Emails are one of the most widely-used forms of communication in the institutional context since they are pervasive in lecturer-student exchanges. This study analyzes opening and closing sequences in first-contact emails written by two groups of students with similar characteristics: one group employed their mother tongue (Spanish) and the second their foreign language (English) when making a request to one of their lecturers. Results show that regardless of language, openings did not show the degree of formality expected in this type of emails. In contrast, closings revealed deference and respect to the lecturer in both kinds of emails.
\end{abstract}

Keywords: openings, closings, email, power distance. 


\section{Introduction}

In the academic context, the use of email in student-lecturer interactions has become increasingly popular over the last 20 years. According to Economidou-Kogetsidis (2011), students are encouraged to use email in their exchanges. In this sense, "studentfaculty interactions at the university level have undergone a shift from face-to-face office hour consultations /.../ to more and more 'cyber-consultations' between students and faculty" (Biesenbach-Lucas, 2006, p. 81). Especially in first-contact emails sent by students requesting feedback, advice or tutorship, the need to use specific politeness formulae so as not to threaten the recipient's face is evident (Brown \& Levinson, 1987). The students may also face additional difficulties when writing emails due to their asymmetrical relationship and the degree of imposition of the request, and also because of their limited pragmalinguistic competence (e.g., the ability to use language to express appropriate utterances), which may result in perceived impoliteness or offence on the lecturer's part. Accordingly, greetings and closings in emails are regarded as essential variables in "maintaining politeness and showing respect towards the addressee" (Hallajian \& David, 2014, p. 86). These authors also argued for the need to draw attention to authentic emails instead of more controlled data arising from, for example, discourse-completion tasks. In this sense, the present study attempts to analyse real opening and closing formulae in first-contact student-initiated emails sent to their lecturer taking into account the variable of power distance in Spain (Hofstede $\&$ Hofstede, 2005).

\section{Theoretical Framework}

\subsection{Hofstede's power distance index}

The Hofstede Model (Hofstede, 2001; Hofstede \& Hofstede, 2005) constitutes a framework to analyse cross-cultural communication. In this model five dimensions of national cultures are described, namely, power distance, individualism/collectivism, masculinity/feminity, uncertainty avoidance, and long-/short-orientation. These dimensions depict the deeply-ingrained values of different cultures, which have an impact on the behaviour of people from distinct cultures and also on the way in which they may behave in a work context. In Hofstede's model, 76 countries were analysed for each dimension, obtaining a score from 0 to 100 . Broadly speaking, higher scores are found for East European, Latin, Asian and African countries, and lower scores for Germanic and English-speaking Western countries (De Mooij \& Hofstede, 2010). For the purposes of the present study, the first dimension (i.e., power distance) is at stake. The power distance index measures "the extent to which the less powerful members of institutions and organizations within a country expect and accept that power is distributed unequally" (Hofstede, 2001, p. 9). In this model, Spain scores relatively 
high in the rank (57), which means that it is a hierarchical society in which bosses' and teachers' authority should not be questioned. Everyone has a place and no justification for unequal power distribution is needed. For example, respect and authority are implemented by means of the expressions usted, the formal variant of tú (Hofstede, Hofstede \& Minkow, 2010).

According to Lan (2000), both the sender's origin and the fact of being a non-native speaker of the target language, among other factors, may affect the degree of formality in emails. (In)formality and (in)directness were two aspects under analysis in Lorenzo-Dus and Bou-Franch's (2013) study, which addressed Peninsular Spanish and British English. These authors claim that the former is generally more informal and direct than the latter in different speech situations. Spain has been characterized as a positive politeness culture (Haverkate, 2003), and, accordingly, Peninsular Spanish shows, for example, the use of unmitigated requests (e.g., requests with no softening devices to reduce the imposition) because the addressee is considered as a "member of an in-group, a friend, a person whose personality traits are known and liked" (Brown \& Levinson, 1987, p. 70). Yet, the particular speech act of requesting is regarded as a face-threatening act since the requester is impeding the requestee's freedom and it might make the interlocutor lose face or damage it in some way. Therefore, the requester's task is to minimize or mitigate the threat by means of politeness expressions such as downtoners (just, maybe, possibly) or the word please.

\subsection{Openings and closings in email communication}

Some authors have claimed (Laborda, 2003) that emails have come to substitute letters in the last century; however, some elements of the epistolary format can also be found in institutional/formal email conversations (Chen, 2006). In this sense, openings (or salutations, greetings) and closings (or signatures, farewells) are optional elements in email communication (Crystal, 2006). Previous research shows great variation in the use of opening and closing sequences. For example, Gains' (1998) study in institutional settings revealed that $92 \%$ of the emails had no opening; similarly, Lan (2000) found out that $54 \%$ of the emails in her corpus also lacked an opening. In exchanges among Australian and Korean academics, Murphy and Levy (2006) claimed that the use of greetings and closings is a way to show politeness and formality en email communication. Bou-Franch's (2011) study showed that in emails between unequals (i.e., students and lecturers), greetings predominated and closings "contained eight times more thanking moves than emails sent down" (Bou-Franch, 2011, p. 1781). These results support the fact that, due to the asymmetric nature of emails among lecturers and students, the absence of openings or closings may result in impolite behaviour.

Variation is also exhibited in closing formulae, although there are two elements which seem necessary to sign off the email: a pre-closing formula and the name of the 
sender (Crystal, 2006). According to this author's data, no instances of avoidance of closing formulae were found; however, other research has shown different results: in his institutional sample, Gains (1998) found $8 \%$ of emails without a closing, and a much higher percentage (25\%) was obtained by Lan (2000). The absence of closing formulae may result in perceived impoliteness on the recipient's part, especially when the email is a request to a higher-up.

\section{Methodology}

\subsection{Purpose and research questions}

This investigation is framed within the university academic context, in which opening and closing sequences are pervasive, according to Bou-Franch (2011). Yet this author claimed for more research to confirm this argument, and the present study aims to address this need. Therefore, the pragmalinguistic variation in the realization of opening and closing sequences in email communication will be examined taking into account the power distance index for Spain. On the basis of previous research on openings and closings in email discourse (Bou-Franch, 2011; Félix-Brasdefer, 2012), we have formulated the following research questions:

- RQ 1: What are the opening and closing realizations of Spanish students writing emails in Spanish?

- RQ 2: What are the opening and closing realizations of Spanish students writing emails in English?

- RQ 3: Are there differences in openings and closings between these two groups of students?

This study is innovative in the sense that it addresses emails written by Spanish students when establishing a first-contact exchange with their lecturers. Previous research has looked at emails sent to faculty members, for example, Spanish students writing in Spanish (Bou-Franch, 2006), non-native English speakers writing in English vs. native speakers (Lan, 2000) or non-native students (Iranian) vs. native English (Eslami, 2013). Also, most research on email communication has been mainly comparative, i.e., native vs non-native (Tseng, 2015). Yet, to our knowledge, no study has examined whether there are pragmalinguistic differences between Spanish speakers writing request emails in Spanish and in English. Moreover, previous research on emails has mainly focused on the request head act to examine politeness (for example, Biesenbach-Lucas, 2007; Chen, 2006), but fewer studies have tackled opening and closing formulae. Furthermore, previous research on email conversations involving students and lecturers (Bou-Franch, 2011; Economidou-Kogetsidis, 2011) did not focus on students' first-contact emails as the lecturers and the students knew each other. The present study aims at shedding further light on these gaps. 


\subsection{Data collection}

All emails under analysis were written by Spanish graduate students addressing a lecturer of a Spanish university. For the purposes of the present study, 25 emails written in Spanish and 25 written in English were selected. To ensure comparability between both groups, these emails shared the following features:

- They were first-contact emails requesting information about enrolment in a master's programme, deadlines or about guidance in the master's thesis elaboration.

- The students' level of proficiency was, in all cases, above B2 in English (Common European Framework of Reference for Languages). As for their L1, they were native speakers of Spanish.

- The power distance variable was stable (unequal-status relationship in institutional context).

\section{Results and discussion}

In an attempt to answer the first research question, a descriptive analysis in terms of frequencies and percentages follows (Table 1).

Table i. Opening and closing realizations in emails written in Spanish

\begin{tabular}{|l|l|l|l|}
\hline \multicolumn{1}{|c|}{ Openings } & \% (frequency) & \multicolumn{1}{c|}{ Closings } & \% (frequency) \\
\hline No greeting & $4 \%(1)$ & Only thanks & $8 \%(2)$ \\
\hline Only greeting & $44 \%(11)$ & Only leave-taking & $8 \%(2)$ \\
\hline $\begin{array}{l}\text { Greeting + lecturer's } \\
\text { first name }\end{array}$ & $44 \%(11)$ & $\begin{array}{l}\text { Leave-taking + } \\
\text { student's first name }\end{array}$ & $8 \%(2)$ \\
\hline $\begin{array}{l}\text { Greeting + lecturer's } \\
\text { title + full name }\end{array}$ & $8 \%(2)$ & $\begin{array}{l}\text { Leave-taking + } \\
\text { student's full name }\end{array}$ & $20 \%(5)$ \\
\hline & & Thanks + leave-taking & $16 \%(4)$ \\
\hline & $\begin{array}{l}\text { Thanks + student's } \\
\text { full name }\end{array}$ & $12 \%(3)$ \\
\hline & $\begin{array}{l}\text { Thanks + leave-taking } \\
\text { + student's first name }\end{array}$ & $16 \%(4)$ \\
\hline & $\begin{array}{l}\text { Thanks + leave-taking } \\
\text { + student's full name }\end{array}$ & $12 \%(3)$ \\
\hline
\end{tabular}

Our results show that in only one email (4\%) in the Spanish corpus the student did not greet the lecturer in the opening sequence, very close to Félix-Brasdefer's (2012) 
findings. In this case, the student directly introduced herself and requested the lecturer's guidance on her master's thesis. The lack of greeting, according to EconomidouKogetsidis (2011), may render the email more direct, as a greeting can serve as small talk. Another possible explanation for the lack of greetings is put forward by Bou-Franch (2006): greetingless emails allow the email sender "to avoid the difficult situation of choosing form of address" (Bou-Franch, 2006, p. 70). In contrast, our data reveal higher percentages when the students did greet the addressee: $44 \%$ of openings were realized by the 'Only greeting' category, although these greetings were implemented in several forms, depending on the time of the day the email had been written (Buenas tardes (Good evening), Buenos dias (Good morning), or simply Hola (Hello). Similarly, 44\% of openings included a greeting along with the first name of the lecturer $(H o l a+$ lecturer's first name). To a much lesser extent (8\%), some students provided a greeting followed by the lecturer's title and name (for example, Buenas tardes Dra. + lecturer's full name).

In light of these results, this particular group of data does not seem to adhere much to the variable of power distance set for Spain, because if we take into account the first three categories from Table 1 (that is, No greeting, Only greeting and Greeting + lecturer's first name), they amount to $92 \%$ of openings which are not deemed as polite by Hallajian and David (2014). Lack of polite openings is somewhat supported by the fact that in only $64 \%$ (16 out of 25 ) of the emails, below the opening formula the student's self-identification was found, either with the expression Soy (I'm) + student's name or Me llamo (My name is) + student's name, as example (1) shows:

(1)

Buenas tardes, [Good afternoon,]

Mi nombre es (student's first name + last name) y soy estudiante del máster (master's name). El año pasado realicé el trabajo fin de grado con mi tutora (name of supervisor). Me gustaría que fueras mi tutora en el trabajo fin de máster, si fuera posible. [My name is (student's first name + last name) and I'm a student in the master (master's name). Last year I elaborated my bachelor's thesis with my supervisor (name of supervisor). I would like you to be my supervisor for the MA thesis, if possible.]

Gracias por la atención y un saludo! [Thanks for your attention and regards!]

In 9 mails (36\%) there was no student's identification before making the request, a fact that may be regarded as impolite behaviour, as in first-contact emails one is supposed to introduce or identify him/herself before the request. In those exchanges in which the students did not identify themselves at the beginning of the email they did so when signing off.

In light of our results, we may claim that the degree of formality ${ }^{1}$ expected in these unequal-status emails only shows in $8 \%$ of the cases with the sequence Greeting +

1. Formality in the body of the email was also expressed by usted, but this analysis was beyond the scope of the present study. 
lecturer's title + full name. Therefore, this finding does not lend support to Hofstede and Hofstede's (2005) power distance index as in over $80 \%$ of the openings the students preferred a more egalitarian opening, by means of only a greeting, with or without the lecturer's name. In this sense, our results are in line with Moreno's (2003) claims that in contemporary Spain the speaker is concerned about his/her listener's positive face regardless of the interlocutor's age or status. Similar findings are reported by Alcón (2015) in her study with Spanish teenagers sending request emails to their teachers. The author argues that lack of mitigation is due to the fact that these students "do not perceive their relationship with their learning mentor as one of social distance" (Alcón, 2015, p. 40).

As for the closing formulae, Table 1 illustrates a wider variation, since eight categories have been identified. To start with, the emails which sign off thanking the lecturer or only provide a leave-taking formula ${ }^{2}$ (with or without the student's name) score low (8\% each). These findings are in line with Félix-Brasdefer (2012), as he also reported low scores in these types of closings. Our data show that the highest percentage (20\%) belongs to the category in which the student fully identifies him/herself with his name and last name after the leave-taking, closely followed by the formula Thanks + leavetaking and Thanks + leave-taking + student's full name (both 16\%).

The use of Gracias (Thanks) or Muchas gracias (Many thanks) seems natural in this type of emails, since the students have requested help or information. This polite behaviour reflects the students' awareness of the unequal relationship with their lecturer, in line with Eslami (2013). The results for closing formulae seem to suggest, on the one hand, students' concern about formality attempting to mitigate the imposition of the request, and on the other, the tendency to adhere to traditional epistolary format.

The findings for the second research question (see Table 2) show that there was one occurrence of a greetingless email and 5 emails opened only with a greeting in the form of Good morning/Good afternoon/Hello. The highest number of emails contained a greeting together with the lecturer's first name. To a much lesser extent, only one email was addressed to the lecturer with the academic title Professor.

The opening formulae in the English data, therefore, are not characterized by formality, disconfirming Ebsworth, Bodman and Carpenter's (1996) findings. The use of the lecturer's first name in this type of emails does not conform to politeness criteria and also departs from the power distance index expected, as they do not show deference to the lecturer. In fact, no greeting or the omission of the form Dear can be regarded as a pragmatic infelicity in these asymmetrical exchanges (Economidou-Kogetsidis, 2011). In addition, the use of Dr. + lecturer's first name (for example, 'Dr. María') is an unacceptable construction in English, along with the use of an incorrect academic title (Mrs. + lecturer's last name).

2. Leave-taking formulae (Good-bye, Saludos) refer to the phatic function of language, in this case to close the email. 
TABle 2. Opening AND CLOSING REALIZATIONS IN EMAILS WRITTEN IN ENGLiSH

\begin{tabular}{|c|c|c|c|}
\hline Openings & $\%$ (frequency) & Closings & $\%$ (frequency) \\
\hline No greeting & $4 \%(1)$ & Only thanks & $8 \%(2)$ \\
\hline Only greeting & $20 \%(5)$ & $\begin{array}{l}\text { Leave-taking + } \\
\text { student's first name }\end{array}$ & $8 \%(2)$ \\
\hline $\begin{array}{l}\text { Greeting + lecturer's } \\
\text { first name }\end{array}$ & $68 \%(17)$ & $\begin{array}{l}\text { Leave-taking }+ \\
\text { student's full name }\end{array}$ & $4 \%(1)$ \\
\hline $\begin{array}{l}\text { Greeting + lecturer's } \\
\text { full name }\end{array}$ & $4 \%(1)$ & Thanks + leave-taking & $8 \%(2)$ \\
\hline \multirow[t]{3}{*}{$\begin{array}{l}\text { Greeting + 'Professor'+ } \\
\text { lecturer's last name }\end{array}$} & $4 \%(1)$ & $\begin{array}{l}\text { Thanks + leave-taking } \\
\text { + student's first name }\end{array}$ & $8 \%(2)$ \\
\hline & & $\begin{array}{l}\text { Thanks + leave-taking } \\
\text { + student's full name }\end{array}$ & $36 \%(9)$ \\
\hline & & $\begin{array}{l}\text { Thanks + student's } \\
\text { first name }\end{array}$ & $28 \%(7)$ \\
\hline
\end{tabular}

Turning our attention to closings, results reveal a high percentage (80\%) of emails which included a thanking formula, often together with a leave-taking. Given the fact that all the emails involved a request, thanking the lecturer in advance may be considered a way to soften or mitigate the students' imposition, as example (2) depicts:

(2)

Good morning! I'm (student's full name), an online student of (name of subject).

(request asking for information about deadlines)

Thank you very much,

(student's full name)

A further category (Thanks + student's first name) was added in the English data as there were 7 emails which were signed off by thanking the teacher followed by only the student's first name, a category which had not been identified in the Spanish data, as example (3) illustrates:

(3)

Good morning,

(request)

Thank you very much for your attention.

(student's first name) 
The third research question asked whether there would be differences in the opening and closing realizations between the two groups of emails. Table 3 displays the percentages in our data, indicating the overwhelming presence of openings and, above all, closings in both kinds of emails. These results are in line with Hatch's claim noting that an email writer "may or may not provide an additional opening, but will have to generate a closing" (Hatch, 1992, p. 13). Yet, and despite the high use of opening and closing formulae this group of students employed when writing their emails to the authoritative figure (lecturer), the degree of formality expected in the opening realizations did not show either in the Spanish or in the English data, as attested by the results of our first and second research questions. The biggest differences between the Spanish and the English emails can be found in the category Only greeting and Greeting + lecturer's first name. In the former, the Spanish data doubles the English (44\% vs 20\%), and in the latter, the percentage of emails written in English is much higher than the one obtained in the Spanish corpus (68\% vs $44 \%)$. A possible explanation for the use of a greeting word in the Spanish emails lies in the fact that the use of Buenos dias (more formal) or Hola (more informal) is a highly standardized way of salutation in Spanish. It is also likely that, due to the hybrid nature of computer-mediated communication (LorenzoDus \& Bou-Franch, 2013), the students may have used characteristics of oral speech in their emails, which may result in more egalitarian communication in detriment of formality. Again, these results seem not to corroborate Hofstede's (2001) power distance index for Spain and they are in line with previous research. For example, Alcón (2013) claimed that the international English speakers (mainly Spaniards) in her study did not consider their relationship with their mentor as involving social distance, and thus they tended to use more informal greetings.

TAble 3. Opening and Closing Realizations in the tWo types of EMail Data

\begin{tabular}{|l|c|c|}
\hline & Emails written in Spanish & Emails written in English \\
\hline Openings & $96 \%$ & $96 \%$ \\
\hline Closings & $100 \%$ & $100 \%$ \\
\hline
\end{tabular}

Our findings reveal low percentages in minimal closings (i.e., Only thanks and Leavetaking + student's first name) both in Spanish and English mails. The picture changes when the closing becomes more complex: for example, the categories Thanks + leavetaking and Thanks + leave-taking + student's first name are twice as high in the Spanish data. However, in the case of Thanks + leave-taking + student's full name, the number of English emails is three times higher than the emails written in Spanish (36\% vs 12\%). This disparity in results may suggest that students writing emails in English adhere to a more formal letter-writing structure, in which, apart from the appreciative formula 
Thanks, a leave-taking and their full name are included to increase the degree of respect to the lecturer.

The coincidence in the percentages from Table 3 may be linked to the fact observed by Wei (2010) that, although a universal phenomenon, greetings are culture specific. Therefore, Spanish speakers may have transferred Spanish opening formulae to English when greeting and the same circumstance may be applied when signing off their emails. This fact lends support to Tseng's (2015) claims that non-native students "can only resort to their existing L1 pragmatics" (Tseng, 2015, p. 26), due to their limited pragmalinguistic competence.

\section{Conclusion}

The prevalent use of emails in student-lecturer communication makes it necessary to employ status-congruent language, especially in first-contact emails in which no familiarity is presupposed. The analysis of openings and closings in the present paper reveals that there is a high occurrence of those moves in email communication, in line with Bou-Franch (2011) and Hallajian and David (2014). Due to the high power distance index set for Spain (Hofstede, 2001), markers of politeness in the email openings and closings were expected so as to account for inequality and power differences. However, openings in both groups of data did not reveal politeness or deference. Contrarily, closings may be regarded as respectful both in the Spanish and in the English data since our findings show enough status-appropriate deference to the lecturer. These findings may have important pedagogical implications both in the L1 classroom and in the English-as-a-foreign-language classroom. Instruction on how to write appropriate openings seems to be an urgent task in light of our results. Openings in emails which may sound too familiar or rude to the recipient might result in not getting a reply on the part of the lecturer. This is a relevant aspect in the university context, in which deference and respect are expected, especially in first-contact emails. In this sense, we adhere to Biesenbach-Lucas' (2005) urge on the need of training how to write effective emails so as to avoid pragmatic infelicities. Moreover, awareness-raising tasks using natural data (such as the opening and closings under analysis in this paper) may prove useful in making learners notice politeness and formal expressions. Also, other factors (e.g., age, status and power of participants, degree of imposition) could be looked in order for learners to understand how relevant they are to avoid sociopragmatic failure.

Our study is a contribution to the body of research on openings and closings in email communication. Although the sample was small, we believe that it has revealed that, in the case of openings in both languages (Spanish and English), the forms of address do not match the expected Power Distance Index in Spain. The openings written in Spanish cannot be regarded as polite, and this fact seems to be transferred to the ones written in English, in which polite or formal markers are a minimal percentage and the use of the lecturer's first name almost reaches $70 \%$. 
This paper presents some limitations. First, students share the same characteristics (i.e., same mother tongue, similar level of proficiency in English) and thus, any conclusion deriving from our analysis may not be applicable to other contexts. Second, the limited number of emails examined does not make results generalizable. Therefore, more research including different levels of proficiency and a wider sample is needed. This may shed further light on how politeness is shown in email openings and closings, a fact that might have an impact on the lecturers' quick reply and also on their positive feedback (Tseng, 2015). Moreover, further research should address opening and closing realizations of subsequent mails after the student's first-contact one. As BiesenbachLucas (2007) states, less formal formulae may arise with more contact between students and their lecturers. Also, issues of punctuation and capitalization (Lan, 2000) are in need of more investigation as they may affect the institutional expectations of email communication. Although the current study focused on a small sample of emails, in our opinion it may widen the scope of email communication by shedding light on how a specific group of graduate students with similar features write to their lecturers for the first time. We concur with Chen's (2006, p. 36) idea of "email literacy", an issue which deserves further attention in the field of education due to the possible negative consequences a lack of pragmatic competence may bring about when foreign-language learners use the email to address their professors.

\section{Acknowledgements}

As a member of the LAELA (Lingüística Aplicada a l'Ensenyament de la Llengua Anglesa) research group at Universitat Jaume I (Castellón, Spain), I would like to acknowledge that this study is part of a research project funded by (a) the Spanish Ministerio de Economía y Competitividad (FFI2016-78584-P), (b) the Universitat Jaume I (P1.1B2015-20), and (c) Projectes d'Innovació Educativa de la Unitat de Suport Educatiu 3457/17.

\section{References}

Alcón, E. (2013). Mitigating e-mail requests in teenagers' first and second language academic cyber-consultation. Multilingua, 32(6), 779-799. doi:10.1515/multi-2013-0037

Alcón, E. (2015). Instruction and pragmatic change during study abroad email communication. Innovation in Language Learning and Teaching, 9(1), 34-45. doi:10.1080/17501229.2014.995763

Biesenbach-Lucas, S. (2005). Communication topics and strategies in e-mail consultation: Comparison between American and international university students. Language Learning \& Technology, 9(2), 24-46. Retrieved from http://lt.msu.edu/ vol9num2/biesenbachlucas/ 
Biesenbach-Lucas, S. (2006). Making requests in e-mail: Do cyber-consultations entail directness? Toward conventions in a new medium. In K. Bardovi-Harlig, J. C. Félix Brasdefer and A. Omar (Eds.), Pragmatics and Language Learning (pp. 81-107). Honolulu: University of Hawaii Press.

Biesenbach-Lucas, S. (2007). Students writing emails to faculty: an examination of e-politeness among native and non-native speakers of English. Language Learning \& Technology, 11(2), 59-81. Retrieved from http://ltt.msu.edu/vol11num2/ biesenbachlucas/

Bou-Franch, P. (2006). Solidarity and deference in Spanish computer-mediated communication: a discourse-pragmatic analysis of students' emails to lecturers. In P. Bou-Franch (Ed.), Ways into discourse (pp. 61-79). Granada: Editorial Comares.

Bou-Franch, P. (2011). Openings and closings in Spanish email conversations. Journal of Pragmatics, 43(6), 1772-1785. doi:10.1016/j.pragma.2010.11.002

Brown, P., \& Levinson, S. (1987). Politeness: Some universals in language usage. Cambridge: Cambridge University Press.

Chen, E. C. F. (2006). The development of e-mail literacy: From writing to peers to writing to authority figures. Language learning \& Technology, 10(2), 35-55. Retrieved from http://llt.msu.edu/vol10num2/chen/

Crystal, D. (2006). Language and the Internet. Cambridge: Cambridge University Press.

De Mooij, M., \& Hofstede, G. (2010). The Hofstede model. Applications to global branding and advertising strategy and research. International Journal of Advertising, 29(1), 85-110. doi:10.2501/S026504870920104X

Ebsworth, M. E., Bodman, J. W., \& Carpenter, M. (1996). Cross-cultural realization of greetings in American English. In S. M. Gass and J. Neu (Eds.), Speech acts across cultures: Challenges to communication in a second language (pp. 89-107). Berlin: Mouton de Gruyter.

Economidou-Kogetsidis, M. (2011). 'Please answer me as soon as possible': Pragmatic failure in non-native speakers' email requests to faculty. Journal of Pragmatics, 43, 3193-3215. doi:10.1016/j.pragma.2011.06.006

Eslami, Z. (2013). Online communication and students' pragmatic choices in English. Lodz Papers in Pragmatics, 9(1), 71-92. doi:10.1515/lpp-2013-0005

Félix-Brasdefer, C. (2012). Email openings and closings: Pragmalinguistic and gender variation in learner-instructor cyber consultations. In E. Alcón and M. P. Safont (Eds.), Discourse and language learning across L2 instructional settings (pp. 223-248). Amsterdam: Rodopi.

Gains, J. (1998). Electronic mail - a new style of communication or just a new medium: an investigation into the text features of email. English for Specific Purposes, 18(1), 81-101. Available at https://eric.ed.gov/?id=EJ577541

Hallajian, A., \& David, M. K. (2014). "Hello and good day to you dear Dr. ..." Greetings and closings in supervisors-supervisees email exchanges. Procedia-Social and Behavioral Sciences, 118, 85-93. doi:10.1016/j.sbspro.2014.02.012 
Hatch, E. (1992). Discourse and language education. Cambridge: Cambridge University Press.

Havertake, H. (2003). El análisis de la cortesía comunicativa: Categorización pragmalingüística de la cultura española. In D. Bravo (Ed.), Actas del Primer Coloquio del Programa EDICE. La perspectiva no etnocentrista de la cortesía: Identidad sociocultural de las comunidades hispanohablantes (pp. 60-70). Stockholm: Stockholms Universitet.

Hofstede, G. (2001). Culture's consequences. Differences in work-related values. Beverly Hills: Sage.

Hofstede, G., \& Hofstede, G. J. (2005). Cultures and organizations. Software of the mind. ( $2^{\text {nd }}$ ed.). New York: McGraw-Hill.

Hofstede, G., Hofstede, G. J., \& Minkow, M. (2010). Cultures and organizations: Software of the mind. (3 ${ }^{\text {rd }}$ ed.). New York: McGraw-Hill.

Laborda, X. (2003). Estilo y cortesía en el correo electrónico. Tonos. Revista Electrónica de Estudios Filológicos, 6. Retrieved from http://www.tonosdigital.es/ojs/index.php/ tonos/article/view/503

Lan, L. (2000). Email: A challenge to Standard English? English Today, 16(4), 23-29. doi:10.1017/S0266078400000511

Lorenzo-Dus, N., \& Bou-Franch, P. (2013). A cross-cultural investigation of email communication in Peninsular Spanish and British English: The role of (in)formality and (in)directness. Pragmatics and Society, 4(1), 1-25. doi:10.1075/ps.4.1.01lor

Moreno, M. C. (2003). El uso del pronombre tú en la España contemporánea: ¿Extensión de un nuevo uso o continuación de una tendencia iniciada en el Siglo de Oro? Actes du Colloque International de Pronoms de Deuxieme Personne et Formes d'Addresse dans les Langues d'Europe. Retrieved from http://cvc.cervantes.es/lengua/coloquio_paris/ ponencias/pdf/cvc_moreno.pdf

Murphy, M., \& Levy, M. (2006). Politeness in intercultural email communication: Australian and Korean perspectives. Journal of Intercultural Communication, 12(6). Retrieved from https://www.immi.se/intercultural/nr12/murphy.htm

Tseng, C. H. (2015). 'You must let me pass, please!': An investigation of email request strategies by Taiwanese EFL learners. Journal of ELT and Applied Linguistics, 3(1), $11-28$.

Wei, L. (2010). The functions and use of greetings. Canadian Social Science, 6(4), 5662. doi:10.3968/j.css.1923669720100604.006 